\title{
PERAN KEPALA SEKOLAH DALAM PENGEMBANGAN MANAJEMEN SEKOLAH SEBAGAI UPAYA MENINGKATKAN MUTU PENDIDIKAN DI SD PLUS ISLAM EXCELLENT BUKITTINGGI
}

\author{
Fakhri Syafrizal \\ Pegawai Tata Usaha SD Negeri 11 Kapeh Panji \\ Kecamatan Banuhampu, Kabupaten Agam \\ e-mail: fakhripanji234@gmail.com
}

\begin{abstract}
This research aimed at understanding about the role of principal to develop the management to upgrade the educational quality in SD Islam Plus Excellent, Bukittinggi. The educational quality needs the role of principal to make the programs. To get the data, I applied interview and documentation. The results revealed that the principal did make the programs related to management of curriculum, student, teachers and employee, financial, infrastructure, special sevice and relationship to upgrade the educational quality.
\end{abstract}

Keywords: Principal, Management, Educational Quality, SD Islam Plus Excellent, Bukittinggi.

\section{PENDAHULUAN}

Dinamika perubahan di zaman sekarang ini memberikan pengaruh yang terhadap paradigma dan cara berpikir masyarakat. Perubahan demi perubahan yang terjadi menuntut semua orang untuk merespon perubahan tersebut. Perubahan yang terjadi menuntut manusia untuk berpikir ke depan, berpikir untuk mendapatkan hasil yang lebih baik di masa yang akan datang. Untuk mendapatkan hasil yang baik di masa yang akan datang, tentu perlu ada rencana dan persiapan di masa sekarang. Saud dan Makmun (2009: 3) menyatakan pada hakikatnya perencanaan merupakan sebuah rangakaian proses kegiatan dalam menyiapkan keputusan mengenai apa yang diharapkan dan apa yang harus dilakukan. Setiap proses yang dilaksanakan agar harapan tersebut terwujud menjadi sebuah kenyataan di masa yang akan datang. Hal ini senada dengan firman Allah SWT dalam AlQur'an "Hai orang-orang yang beriman, bertakwalah kepada Allah dan hendaklah setiap diri memperhatikan apa yang telah diperbuatnya untuk hari esok (akhirat); dan bertakwalah kepada Allah, sesungguhnya Allah Maha Mengetahui apa yang kamu kerjakan" (Q.S Al Hasyr 18).

Firman Allah SWT di atas menuntun manusia agar memperhatikan apa yang telah diperbuatnya untuk masa yang akan datang, sebab masa yang akan datang merupakan hasil yang didapat dari apa yang dilakukan di masa sekarang. Kalau seseorang melakukan yang baik di masa sekarang, maka berdampak baik di masa yang akan datang, namun begitu juga sebaliknya. Oleh karena itu perlu sebuah persiapan dan rencana yang baik di masa sekarang agar harapan yang 
baik juga terwujud di masa yang akan datang.

Sehubungan dengan ayat di atas, usaha untuk merencanakan hasil yang baik di masa yang akan datang, membutuhkan sebuah wadah yang diharapkan dapat mewujudkan harapan dan cita-cita yang direncanakan tersebut. Harapan dan cita-cita akan lahirnya generasi yang bermutu, tentu harus direspon dengan usaha membangun sebuah wadah untuk menampung harapan tersebut. Hal ini erat kaitannya dengan pendidikan, yang mana seperti yang dituliskan dalam Undang- Undang Sisdiknas No. 20 Tahun 2003 menyatakan bahwa pendidikan adalah sebuah usaha sadar dan terencana untuk mewujudkan suasan belajar dan proses pembelajaran agar peserta didik secara aktif mengembangkan potensi dirinya untuk memiliki spiritual keagamaan, pengendalian diri, kepribadian, kecerdasan, ahklaq mulia, serta keterampilan yang diperlukan dirinya, masyarakat, bangsa dan negara. Senada dengan itu, Basri (2009: 54) mengemukakan bahwa pendidikan adalah proses pembinaan jasmani dan rohaani, upaya dalam meningkat kecerdasan, intelektual, emosional dan spiritual, menjadikan peserta didik memiliki kemampuan dan keahliah profesioanl yang dapat memberikan manfaay bagi masysrakat. Dapat disimpulkan bahwa pendidikan sebagai usaha untuk melahirkan manusia yang berkualitas.

Untuk menjawab kebutuhan akan mutu dari sebuah pendidikan, perlu adanya usaha dan upaya agar mutu yang diharapkan bisa tercapai. Sebuah lembaga pendidikan yang merupakan wadah untuk membangun generasi yang bermutu diharapkan mampu menciptakan pendidikan yang bermutu agar melahirkan generasi yang bermutu. Agar kebutuhan masyarakat akan sebuah mutu bagi generasi mereka terpenuhi, lembaga pendidikan harus berusaha dan berupaya untuk mengelola pendidikan tersebut sebaik mungkin, sehingga kebutuhan masyarakat tersebut bisa terpenuhi. Menyadari hal tersebut di saat sekarang ini, setiap lembaga pendidikan berusaha dan berupaya untuk menciptakan pendidikan yang bermutu. Berbagai cara, langkah dan strategi dilakukan agar mutu tersebut bisa dicapai. Tanpa adanya usaha, tidak akan mungkin sebuah harapan akan terwujud. Hal ini dapat dilihat dari Firman Allah SWT "Sesungguhnya Allah tidak merobah keadaan sesuatu kaum sehingga mereka merobah keadaan yang ada pada diri mereka sendiri” (Q.S Ar. Ra'd 11).

Pendidikan yang bermutu harus dimulai dari dasar. Hal inilah yang dilakukan oleh sebuah lembaga pendidikan dasar yakni Sekolah Dasar Islam Plus Excellent. SD Islam Plus Excellent merupakan salah satu 
sekolah yang menggunakan kurikulum terpadu, yakni integrasi pembelajaran umum dan agama. Sekolah yang mempunyai visi "berprestasi, beriman, bertaqwa, berkarakter, dan berbudaya lingkungan " berupaya untuk membangun sebuah mutu pendidikan tersebut. Hal ini diutarakan oleh salah seorang sekretaris yayasan, di mana salah satu tujuan utama didirikannya sekolah ini adalah untuk menciptakan pendidikan Islam yang berkualitas, sehingga para generasigenerasi Islam dapat menimba ilmu di sekolah tersebut.

Agar mutu tersebut bisa dicapai, perlu adanya langkah-langkah, strategi ataupun kebijakan yang harus dilaksanakan. Langkah ataupun strategi yang dimainkan oleh sebuah lembaga pendidikan, merupakan wilayah kerja seorang kepala sekolah selaku pimpinan di sekolah tersebut. Kepala sekolah sebagai sosok ataupun figur yang menjadi motor penggerak kemajuan lembaga pendidikan tentu memiliki strategi agar sekolah yang dipimpinya menjadi sekolah yang bermutu. Hal ini juga berlaku berlaku begi kepala SD Islam Plus Excellent. Berbagai usaha, langkah dan strategi dilakukan agar sekolah yang dipimpinnya menjadi sekolah yang bermutu.

\section{KEPALA SEKOLAH}

Mulyasa (2009: 24) menyatakan bahwa kepala sekolah merupakan salah satu komponen pendidikan yang paling berperan dalam meningkatkan kualitas pendidikan. Daryanto (2008: 80) juga mengemukan bahwa kepala sekolah merupakan personel yang bertanggung jawab dan memilki kewenangan terhadap semua kegiatan pendidikan dalam lingkungan sekolah yang dipimpinya. Kepala sekolah yang merupakan sosok yang memiliki visi dan misi, serta strategi manejemen pendidikan secara utuh yang berorientasi kepada mutu (Mulyasa 2009: 25). Kepala sekolah sebagai pengelola dan eksekutif yang merupakan pelaksana teknis manajerial memiliki bebagai keterampilan dalam menjalankan sekolah (Rohiat: 2008: 14). Artinya kepala sekolah merupakan sosok pemimpin yang memiliki kemampuan dan keterampilan yang diimplementasikan sebagai strategi dalam meningkatkan mutu pendidikan.

$$
\text { Purwanto (2010: }
$$

mengemukakan bahwa kepala sekolah sebagai administrator pendidikan bertangung jawab terhadap kelancaran pelaksanaan pendidikan dan pengajaran di sekolahnya. Kepala sekolah harus memahami, menguasai dan melaksanakan kegiatan yang berkenaan tugas dan fungsinya sebagai administrator pendidikan. Adapun fungsi-fungsi kepala sekolah sebagai administrator yakni 1) membuat perencanaan; 2) menyusun organisasi sekolah; 3) bertindak sebagai 
coordinator dan pengarah; 4) melaksanakan pengelolaan kepegawaian. Senada dengan itu Rohiat (2010: 37) menyatakan peran utama kepala sekolah selaku pemimpin adalah sebagai berikut: 1) memiliki visi tentang mutu terpadu bagi institusinya; 2) memiliki komitmen tentang pengembangan mutu; 3) mengomunikasikan pesan mutu; 4) meyakini kebutuhan pelanggan sebagai pusat dan praktik organisasi; 5) meyakini semua orang tentang adanya saluran untuk mendengarkan suara pelanggan; 6) memimpin pengembangan staff; 7) tidak menyalahkan seseorang ketika muncul sebuah permasalahan tanpa melihat bukti-bukti; 8) memimpin inovasi dalam organisasinya 9) meyakini bahwa struktur organisasional secara jelas mendefinisikan tanggung jawab dan menyediakan delegasi maksimum dengan akuntabilitas; 10) memiliki komitmen terhadap penghilangan hambatan yang bersifat organisasaional atau kultural; 11) membangun tim efektif dan 12) mengembangkan mekanisme yang cocok untuk monitor dan evaluasi keberhasilan.

\section{MUTU PENDIDIKAN}

Rahardja (2010) mengutip pendapat Gregory B. Hutchins mengemukakan bahwa mutu adalah: 1) Conformance to applicable specifications and standards yaitu sesuai dengan syarat dan standar yang diapakai; 2) Fitness for use yaitu ketepatan penggunaan dan 3) Satisfaction of customer wants,needs, and expectations at a competitive cost yaitu kepuasan akan keinginan, kebutuhan dan harapan pelanggan, serta biaya yang dapat bersaing. Rohiat (2010: 52) menyatakan bahwa mutu atau kualitas adalah gambaran karakteristik menyeluruh dari barang atau jasa yang menujukkan kemampuan untuk memuaskan kebutuhan. Dalam konteks pendidikan pengertian mutu mencakup input, proses, dan output pendidikan.

Pendidikan yang bermutu merupakan garapan seluruh lapisan masyarakat. Pendidikan yang bemutu ditandai dengan mutu lulusan yang memiliki kompetensi dan daya saing yang kuat. Mutu pendidikan merupakan gambaran akan mutu suatu bangsa. Oleh karena itu, perlu adanya usaha dan upaya yang optimal dalam menciptakan pendidikan yang bermutu. Irianto (2011: 117) menyatakan bahwa peningkatan mutu pendidikan tidak terlepas dari proses pembelajaran. Adapun proses pembelajaran sangat tergantung dari tenaga pengajar, peralatan dan sumber-sumber pembelajaran.

\section{METODE PENELITIAN}

Penelitian ini memiliki karakter penelitian lapangan (field research) yang menggunakan pendekatan deskriptif kualitatif. Penelitian deskriptif menurut Sukmadinata (2010: 72) menjelaskan bahwa bentuk penelitian ini ditujukan untuk 
menggambarkan fenomena-fenomena yang terjadi, mengkaji aktifitas, perubahah dan hubungan yang terjadi. Penelitian kualitatif ditujukan untuk memahami partisipan, yakni orang-orang yang diajak berwawancara, dimintai data dan ketarangan, pemikiran, pendapat ataupun persepsi. (Sukmadinata: 2010: 94). Berg (2001: 6) menyatakan "Qualitative research properly seek answers to questions by examining various sosial settings and the individual who inhabit these setting. Qualitative researcher, then, are most interested in how thuman arrange themselves and their setting how inhabitants of these make sense of their surroundings trough symbols, rituals, social structures and social roles, and so forth". Jadi penelitian ini mencoba menggambarkan fenomena yang terjadi dengan mengumpulkan data ataupun informasi dari wawancara, observasi, dan diperkuat dengan dokumen-dokumen pendukung.

Penelitian kualitatif memiliki karakteristik sebagai berikut yakni 1) kajian naturalistik, berjalan secara alamiah tanpa ada yang direkyasa 2) analisis induktif 3) holistic, di mana fenomena dipahami sebagai sistem yang komplek, menyeluruh 4) data kualitatif, deskripsi, rinci-dalam, persepsipengalaman 5) hubungan dan persepsi pribadi, terjadinya keakraban antara peneliti dan informan 6) dinamis 7) orientasi keunikan, memiliki situasi yang khas, dalam konteks sosial-historis dan 8) empati yakni subjektif murni dan tidak dibuat-buat (Sukmadinata, 2010: 95).

Senada dengan hal di atas Sarwono (2006: 193) mengemukakan bahwa riset kualitatif menunjukkan sebuah proses, pemahaman, kompleksitas, interaksi dan manusia. Proses merupakan penekanan pada riset kualitatif, maka penelitian ini lebih berfokus pada proses bukan hasil. Kemudian, pendekatan kualitatif ini dilakukan jika peneliti ingin melakukan hal-hal sebagai berikut yakni 1) memahami makna yang melandasi tingkah laku partisipan 2) mendeskripsikan latar dan interaksi partisipan 3) melakukan eksplorasi untuk mengidentifikasi informasi baru 4) memahami keadaan yang terbatas dan mengetahui secara mendalam dan rinci 5) mendeskripskan fenomena untuk menciptakan teori baru (Sarwono 2006).

Dalam melakukan pengumpulan data, penulis melakukan wawancara dan dokumen. Sukmadinata (2010: 2016) menyatakan bahwa wawancara merupakan tehnik pengumpulan data yang banyak digunakan peneliti kualitatif. Dalam wawancara, peneliti melakukan taatap muka lansung dengan informan. Suryana (2015: 227) menyatakan bahwa selain membawa instrument wawancara, peneliti juga dapat membawa 
alat bantu berupa tape recorder, gambar dan material lainnya yang dapat membatu peneliti dalam menghimpun data. Untuk memperkuat data, peneliti juga menggunakan dokumen. Dengan arti kata, dalam penelitian kualitatif ini, seorang peneliti turun lansung ke lapangan dalam rangka mengumpulkan data dan informasi yang dibutuhkan dalam penelitian.

\section{HASIL PENELITIAN DAN \\ PEMBAHASAN}

SD Islam Plus Excellent yang berada di bawah Yayasan Nur Iman merupakan lembaga pendidikan yang berdiri pada tanggal 1 Juli 2006. Pendiri sekolah ini yang sekaligus pengurus Yayasan Nur Iman ini merupakan businessman yang bergerak di bidang perdagangan. Sekolah ini sengaja didirikan sebagai pengabdian di hari tua untuk menciptakan sebuah pendidikan yang berkualitas. Hal ini disampaikan oleh Bapak Edi selaku sekretaris yayasan Nur Iman. Pendidikan yang berkualitas ini diharapkan mampu menarik minat masyarakat agar menyekolahkan anak-anak mereka ke sekolah ini. Pendidikan yang berkualitas ini diharapkan mampu melahirkan generasigenarasi yang berkualitas yang dapat berkontribusi untuk kemashlahatan umat. Dalam hal ini, yayasan mendirikan sekolah terpadu, yakni keterpaduan antara pendidikan umum dan pendidikan agama. Maka dengan adanya ide tersebutlah lahir sekolah SD Islam Plus Excellent.

Dari data yang diperoleh melalui dokumen profil sekolah, di mana visi SD Islam Excellent ini yakni "Berprestasi, beriman, bertaqwa, berkarakter, dan berbudaya lingkungan". Visi yang mengacu pada cita-cita, harapan, keinginan dan impiann yang dirumuskan secara sederhana, singkat dan padat, namun penuh makna yang sangat luas (Nata: 2005: 30). Visi yang menggambarkan pada kualitas yang diharapkan oleh sebuah lembaga dan organisasi, menuntut akan usaha, upaya dan strategi untuk mencapainya. Tanpa adanya usaha dan strategi, mustahil sebuah visi yang dirumuskan tersebut bisa tercapai. Semua pihak yang terlibat dalam organisasi atau lembaga tersebut harus bekerja keras agar visi yang dirumuskan tersebut dapat dicapai.

Dalam lembaga pendidikan, sebuah visi yang dirumuskan tersebut dicapai dengan melaksanakan proses belajar mengajar. Proses belajar mengajar yang dilakukan terserbut didasari pada kurikulum yang dilaksanakan di sekolah tersebut. Nata (2005: 175) mengutip pendapat Crow and Crow bahwa kurikulum merupakan rancangan pengajaran yang berisikan sejumlah mata pelajaran yang disusun secara sistematis. Wakil Bidang Kurikulum SD Excellent yakni Ibu Sulastri, S.Pd., mengemukakan bahwa 
sekolah yang dipimpinnya menggunakan kurikulum KTSP (Kurikulum Tingkat Satuan Pendidikan) untuk pelajaran umum dan kurikulum 2013 untuk pelajaran Pendidikan Agama Islam. Hal ini juga dinyatakan oleh Kepala Sekolah yakni Ibu Rika Sasriyanti, S.Pd. bahwa kurikulum yang digunakan adalah kurikulum KTSP, dan berkemungkinan nantinya pada tahun ajaran 2016/2017 Sekolah Dasar Excellent Islam Plus akan menggunakan Kurikulum 2013. Di samping itu, kurikulum yang digunakan di sekolah ini juga dipadukan dengan pelajaran agama Islam plus.
Ibu Rika Sasriyanti S.Pd dan Ibu Sulastri, S.Pd mengemukakan bahwa di sekolah Excellent yang menjadi nilai plusnya adalah keterpaduan kurikulum umum dan agama yang mana dalam pembelajarannya di mana sekolah Excellent menambahkan pendidikan Al Qur'an dan Tahfizh Qur'an dalam muatan kurikulum yang digunakan. Hal ini diperkuat dari data yang penulis dapatkan dari dokumen muatan kurikulum pada situs resmi SD Islam Plus Excellent berikut ini.

Tabel 1. Struktur Muatan Kurikulum SD Islam Plus Excellent

\begin{tabular}{cl}
\hline No & \multicolumn{1}{c}{ Kurkulum } \\
\hline I. & 1. Tahfidz Al-Qur'an juz 30, Shalat berjamaah \\
& 2. Seni tilawah Al-Qur'an \\
& 3. Kurikulum terintergrasi antara pelajaran umum dan keagamaan \\
4. Pengembangan minat bakat anak melalui keiatan ekstrakurikuler \\
5. English performance \\
6. Pelatihan olympiade Mata Pelajaran Nasional \\
II. \\
1. Pendidikan Agama Islam \\
2. Pendidikan Kewarganegaraan \\
3. Bahasa Indonesia \\
4. Matematika Berhitung \\
5. Ilmu Pengetahuan Alam \\
6. Ilmu Pengetahuan Sosial \\
7. Kesehatan \\
8. Keterampilan \\
9. Pendidikan Jasmani \\
III. \\
1. Budaya Alam Minangkabau \\
2. Bahasa Inggris \\
3. Komputer \\
4. Pemahaman Al-Qur'an \& Hadits \\
5. TPQ + Al-Qur'an berirama \\
1V. Budaya Alam Minangkabau \\
1. Mukstrakurikuler
\end{tabular}


2. Bahasa Inggris

3. Komputer

4. Pemahaman Al-Qur'an \& Hadits

5. TPQ + Al-Qur'an berirama

Dalam upaya peningkatan mutu pendidikan, Sekolah Dasar Islam Plus Excellent juga melakukan pengembangan kurikulum. Heryati dan Muhsin (2014:156) Pengembangan kurikulum yang mencakup perencanaan, penerapan dan evaluasi, dengan memperhatikan prinsip-prinsip pengembangan kurikulum yakni prinsip relevasi, fleksibelitas, kontinuitas, efesiensi dan efektifitas. Melalui wawancara dengan Ibu Sulastri, S.Pd selaku Waka Kurikulum dijelaskan bahwa pengembangan kurikulum yang dilakukan di SD Islam Plus Excellent melibatkan orang-orang yang ahli di bidang pendidikan, seperti pengawas sekolah berprestasi, di samping melakukan kerja sama dengan pengawas sekolah tersebut. hal ini menunjukkn bahwa dalam upaya peningkatan mutu pendidikan, SD Islam Plus Excellent berusaha untuk membuat pengembangan kurikulum yang bermutu, dengan mendatangkan para ahli tersebut. Para ahli dan pakar pendidikan tersebut sengaja diundang untuk melahirkan kurikulum yang bermutu bagi proses pembelajaran di SD Islam plus Excellent. Kemampuan mengembangkan kurikulum inilah yang menjadi salah satu kunci SD
Islam plus Excellent dalam meningkatkan mutu pendidikan.

Dari sistem perekrutan siswa di pada SD Islam Plus Execellent, dari hasil wawancara (12 Mei 2016) dengan Ibu Rika Sasriyanti selaku Kepala Sekolah mengemukakan bahwa dalam sistem perekrutan siswa baru, sekolah ini melakukan tes kemampuan, di mana bentuk tes yang dilakukan bukan tes tertulis, namun hanya disuruh untuk mengambil bantuk-bentuk bangun ruang seperti bentuk kubus. Hal ini untuk melihat kemampuan rata-rata yang dimiliki oleh siswa. Menurut Prihatin (2014: 52) mengemukakan bahwa dalam manajemen peserta didik, setiap orang mempunyai hak untuk menjadi peserta didik. Namun dalam hal ini, tidak semua orang dapat diterima di suatu lembaga pendidikan. Sebab untuk dapat diterima sebagai peserta didik, tentu ada criteria-criteria dan kewajibann yang harus dipenuhi. Qomar (2007: 143) menyatakan bahwa dalam penerimaan peserta didik baru tetap perlu ada pembatasan. Hal ini dilakukan agar kemampuan yang dimiliki oleh peserta didik dapat berkembang secara optimal. Ini menunjukkan bahwa setiap sekolah bukan hanya memikirkan jumlah peserta didik saja, 
namun kualitas peserta didik juga harus menjadi pertimbangan yang sangat penting. Seorang guru aka kesulitan jika di dalam satu kelas tersebut jumlah siswa melebihi kapasitas yang ditetapkan. Untuk aturan jumlah peserta didik tingkat dasar, untuk satu lokal maksimal sebanyak 28 siswa.

Selanjutnya dalam sistem pembelajaran di SD Islam Plus Excellent, di mana diperoleh data dari wawancara (12 Mei 2016) dengan Kepala Sekolah, di mana sistem pembelajaran yang dilakukan di SD Islam Plus Excellent ini adalah sistem integrasi. Sistem integrasi yang dimaksud di sini adalah terintegrasinya antara mata pelajaran umum dan agama dalam satu ruang lingkup pembelajaran. Proses pembelajaran yang dimulai pada pukul 07.30 WIB dan berakhir pada pukul 15.00 WIB, di mana semua mata pelajaran baik yang umum atau pelajaran agama disatukan di dalamnya.

Pembelajaran agama Islam yang tergabung dalam pelajaran TPQ (Taman Pendidikan Qur'an) diajarkan dengan alokasi waktu sebanyak 24 jam, tergabung dalam susunan mata pelajaran umum. Sebagai contoh, jika jam pertama dan kedua merupakan pelajaran umum, pada jam ketiga dan keempat diajarakan mata pelajaran TPQ ini. di samping proses pembelajaran untuk mengembangkan potensi yang dimiliki para siswa, SD Islam Plus Excellent melakukan pengembangan melalui kegiatan ekstrakurikuler. Kegiatan ekstrakuler yang dilakukkan ini sesuai dengan bakat dan minat siswa, seperti seni musik, tari, bahasa Inggris, tahfizh. Kegiatan ekstrakurikuler ini dilaksanakan setiap hari Sabtu setiap minggunya. Dengan adanya kegiatan ekstrakurikuler ini, setiap siswa dapat mengembangkan bakat dan minat yang mereka miliki. Di samping kegiatan ekstrakurikuler, para siswa juga dilatih untuk mengahadapi olimpiade, seperti sains dan matematika.

Pada tahap selanjutnya, pengamban manajeman tenagan pendidikan dan kependidikan pada SD Islam Plus Exellent Bukittinggi, di mana diperoleh data dari wawancara (12 Mei 2016) dengan kepala sekolah dinyatakan bahwa setiap guru yang ada di SD Islam Plus Exellent Bukittinggi memiliki latar belakang pendidikan $\mathrm{S} 1$ kependidikan. Hal ini sesuai dengan Permen Diknas No. 16 Tahun 2007 tentang Standar Kualifikasi Akademik dan Kompetensi Guru, di mana dinyatakan bahwa kualifikasi akademik guru pada SD/MI, atau bentuk lain yang sederajat harus memiliki kualifikasi akademik pendidikan minimum diploma empat (D-IV) atau sarjana (S1) dalam bidang pendidikan SD/MI (D-IV/S1 PGSD/PGMI) atau psikologi yang diperoleh dari program studi yang terakreditasi. 
Kemudian dalam pengembangan kompetensi tenaga pendidikan, kepala sekolah juga melakuakn berbagai kegiatan pengembangan kompetensi guru. Mukhtar (2015: 108) dalam tulisannya menyatakan bahwa kepala sekolah seyogyanya dapat menfasilitasi dan memberikan kesempatan yang luas kepada para guru untuk melaksanakan kegiatan pengembangan profesi melalui kegiatan pendidikan dan pelatihan, baik yang dilaksanakan di sekolah atau kegiatan di luar sekolah. Adapun bentuk pengembangan dan peningkatan kompetensi guru yang dilakukan di SD Islam Plus Exellent Bukittinggi, di mana sekolah mendatangkan tenaga ahli dari luar daerah seperti Jakarta dan Solo untuk memberikan bimbingan dan pelatihan kepada para guruguru. Di samping itu, para guru-guru di SD Islam Plus Exellent Bukittinggi juga mengikuti kegiatan Kelompok Kerja Guru (KKG) dalam upaya peningkatan kompetensi guru. Di samping itu ada juga kerja sama para guru dengan pihak percetakan buku. Kemudian lagi, guru-guru juga menadapat pelatihan pembuatan bahan ajar menggunakan ICT. Di samping tenaga pendidikan, juga diadakan pelatihanpelatihan untuk tenaga kependidikan. Semua kagiatan-kegiatan pengembangan diri tersebut dilakukan dalam upaya peningkatan mutu dan kualitas pendidikan.
Kegiatan pengembangan dan peningkatan kompetensi guru merupakan upaya peningkatan kinerja guru yang nantinya akan memberikan dampak kepada kualitas atau mutu pendidikan. Menurut Krisna, Bagia dan Yulianthuni (2015:6) menyatakan bahwa indikator kinerja dibagi menjadi 3 yakni 1) loyalitas adalah kesetiaan dan semangat berkorban pegawai agar tujuan organisasi tercapai; 2) tanggung jawab dan kecintaan pada pekerjaan serta siap dalam menghadapi resiko; 3) ketarampilan yakni kemampuan dalam melaksanakan tugas dalam pekerjaan (Lilik, 2009). Peningkatan kinerja guru sebagai upaya dalam mencapai tujuan pendidikan tersebut perlu ditingkat secara terus menerus. Dengan adanya peningtakan kinerja guru tersebut, diharapakan nantinya akan lahir pendidikan yanh berkualitas serta lulusan yang berkualitas.

Dalam sistem pengelolaan keuangan, dari hasil wawancara dengan Ibu Rika Sasriyanti, S.Pd dinyatakan bahwa sumber dana pendidikan di SD Islam Plus Exellent Bukittinggi di dapat dari pemerintah berupa dana BOS (Biaya Operasional Sekolah). Dalam penerimaan dana BOS ini setiap sekolah menerima sebanyak jumlah siswa, di mana untuk satu orang siswa dianggarakan sebesar Rp. 800.000,- per tahun. Penggunan dan BOS ini dialokasikan untuk 
pengembangan delapan standar pendidikan yakni 1) standar porses, 2) standar isi, 3) standar kompetensi lulusan, 4) standar pembiayaan, 5) standar sarana dan prasarana, 6) standar tenaga pendidik dan kependidikan, 7) standar pengelolaan dan 8) implementasi sistem penilaian.

Kemudian, di samping menerima dana BOS dari pemerintah, SD Islam Plus Exellent Bukittinggi ini juga memungut iuran SPP pada setiap murid, rata-rata $\mathrm{Rp}$. 200.000,-. Namun jika dalam sekolah tersebut ada yang bersaudara, siswa orang tua tidak membayar sebanyak yang dianggarakan tersebut. Sekolah ini juga menggratiskan iuran SPP pada siswa-siswa yang diketegorikann siswa kurang mampu. Jika dana BOS digunakan sesuai pengembangan delapan standar pendidikan dan pelaporanyanya pada Dinas Pendidikan, maka kalau iuran dari SPP siswa digunakan untuk membayarkan gaji guru, serta digunakan untuk mendatangkan tenaga ahli dari luar, dan sistem pelaporan dana iuran SPP ini lasung kepada yayasan. Kemudian, selain mendapatkan gaji dari yayasan, para guru juga mendapatkan tunjangan sertifikasi guru non PNS. Mulyasa (2009: 33) menyatakan bahwa sertifikasi guru sebagi suatu proses pengakuan bahwa seseorang telah memiliki kompetensi untuk melaksanakan pelayanan pendidikan pada satuan pendidikan.

Perlu disadarai bahwa lembaga pendidikan dalam menjalankan operasionalnya tidak bisa lepas dari pendanaan. Dana merupakan faktor yang mempengaruhi proses pendidikan harus dialokasikan dan dikelola dengan baik. Berbagai program-program dan kegitan pendidikan bisa terpelaksana dengan baik dengan adanya anggaran biaya. Tak jarang, program-program pendidikan terhambat pelaksanaannya dikarenakan tidak adanya biaya yang dianggarakan. Sebagaimana yang tertuang dalam Undang-Undang Sistem Pendidikan Nasional No 20 Tahun 2003 pasal 46 dinyatakan bahwa pendanaan pendidikan menjadi tanggung jawab bersama antara pemerintah, pemerintah daerah, dan masyarakat. Ini artinya, keberadaan keungan sebuah lembaga pendidikan menjadi tanggung jawab bersama. Namun di samping itu, ada hal yang peling penting, yakni kepercayaan untuk menjaga amanah dalam menggunakan anggaran pendidikan pada jalur-jalur yang dibenarkan.

Untuk meningkatan mutu pendidikan, selaian biaya pendidikan, kebaradaan sarana dan parsarana juga memberikan dampak terhadap peningkatan kualitas dan mutu pendidikan. Rohiat (2010:26) menyatakan bahwa sarana dan prasarana meliputi semua 
benda bergerak dan tidak bergerak yang dibutuhkan untuk penyelenggaraan pendidikan, baik secara lansung dan tidak lansung. Dari hasil wawancara (12 Mei 2016) dengan kepala sekolah, dinyatakan bahwa sarana dan prasarana yang dimiliki oleh SD Islam Plus Exellent Bukittinggi yakni ruang belajar yang dilengkapi dengan proyektor, ruang kepala sekolah, ruang guru, perpustakaan, sarana olah raga dan tempat ibadah. Pernytaan ini diperkuat dengan dokumen profil sekolah yang peneliti dapat tentang kelengkapan sarana dan prasarana sekolah yang dimiliki, di antaranya sebagai berikut.

Tabel 2. Fasilitas Sekolah (Profil SD Islam Plus Excellent)

\begin{tabular}{llc}
\hline No & Fasilitas & Volume \\
\hline 1. & Ruang Kelas & 12 \\
2. & Ruang Guru, Wakil dan Kepala Sekolah & 1 \\
3. & Ruang Tata Usaha & 1 \\
4. & Labor Komputer & 1 \\
5. & Ruang Kesenaian & 1 \\
6. & UKS & 1 \\
7. & Labor IPA & 1 \\
8. & Perpustakaan & 1 \\
9. & Sarana Olah Raga dan Lapangan & 1 \\
10. & Taman Sekolah & 2 \\
11. & Mushalla & 1 \\
12. & Green House & 1 \\
13. & WC & 10 \\
14. & Sarana Parkir & 1 \\
15. & POS Satpam & 1 \\
16. & Gudang & 1 \\
17. & Kantin Sekolah & 1 \\
\hline
\end{tabular}

Di samping menjalani proses pendidikan, SD Islam Plus Exellent Bukittinggi juga menjalin hubungan dengan masyarakat. Dari hasil wawancara dangan kepala sekolah diperoleh data bahwa dalam menjalin hubungan dengan masyarakat, pihak sekolah memiliki program untuk membagikan sembako kepada masyarakat, membantu mushalla dalam bentuk sumbangan, partisipasi siswa dalam membersihkan mushalla serta pihak sekolah juga mengundang masyarakat untuk menghadiri acara khatam Al Qur'an. Masyarakat yang merupakan unsure yang juga terlibat dalam pendidikan ini juga merupakan sebuah wadah bagi pesertan didik untuk mengembangkan dan mengamalkan ilmu yang di dapat dari sekolah.

Pada bagian manajemen layanan khusus, dari hasil wawancara dengan kepala 
sekolah (12 Mei 2016) juga diperoleh data bahwa pihak sekolah melalui wakil kepala sekolah bidang kesiswaan memegang peranan dalam layanan khusus ini. Hal ini, segala permasalahan yang berkaitan dengan kesiswaan, diselesaikan melalui wakil kepala bidang kesiswaan, di samping peranan walim kelas. Rohiat (2010: 23) menyatakan bahwa keberhasilan proses balajar mengajar juga ditunjang oleh layanan khusus seperti bimbingan konseling, pusat sumber belajar, pusat kesehatan sekolah dan kantin sekolah. Jadi keberadaan layanan khusu dalam sebuah lembaga pendidika perlu mendapat perhatian khusus pula, sebab merupakan penunjang keberhasilan proses belajar mengajar.

Uraian di atas menggambarkan proses pengelolaan pendidikan di SD Islam Plus Exellent Bukittinggi. Pengelolaan yang dilakukan mulai dari yayasan sampai pihak sekolah pada intinya untuk membangun sebuan pendidikan yang bermutu dan berkualitas. Pendidikan yang bermutu dan berkualitas akan diminati oleh masyarakat, sebab masyarakat itu sendiri juga menginginkan generasi mereka terlahir sebagai generasi yang berkualitas juga.

Kepala Sekolah, di samping sebagai seorang pimpinan lembaga pendidikan juga merupakan seorang menejer. Sebagai seorang menejer, kepala sekolah mampu mengatur segala bentuk pengelolaan pada lembaga pendidikan. Mulyasa

$(2009: 103)$

mengemukakan bahwa selaku seorang menejer, kepala sekolah harus memiliki strategi dalam memberdayakan tenaga kependidikannya melalui kerja sama dan memberi kesempatan pada tenaga kependidikan untuk meningkatkan profesinya. Andriani (2011: 53) menyatakan bahwa komitmen yang tinggi terhadap tujuan dan pengajaran yang efektif dari seluruh warga sekolah dan stakeholders membutuhkan pengarahan dan bimbingan kepala sekolah. Hal ini menunjukkan bahwa kepala sekolah merupakan motor penggerak lembaga pendidikan, pengatur arah kebijakan dalam rangka mencapai tujuan pendidikan. Rosyadi dan Pardjono (2015: 126) mengemukan bahwa posisi kepala sekolah menentukan arah suatu lembaga, pengatur program sekolah. Kepala sekolah diharapkan membawa spirit kerja guru dan membangun kultur sekolah dalam meningkatkan mutu pendidikan.

Sosok Kepala Sekolah sebagai manajer manuntutnya agar mampu membuat dan mengembangkan program-program peningkatan mutu pendidikan. Mulai dari perencanaan sampai evaluasi, di mana setiap program yang diadakan menjadi tanggung jawab kepala sekolah selaku manejer pendidikan. Mukhtar (2015:104) juga menjelaskan bahwa kepala sekolah harus 
mampu menciptakan suasana yang kondusif dann inovatif dalam melaksanakan kegiatan sekolah. Hal ini sesuai dengan Peraturan Menteri No. 13 Tahun 2007 tentang Standar Kepala Sekolah/Madrasah di mana disebutkan bahwa kepala sekolah mengelola guru dan staf dalam rangka pendayagunaan sumber daya manusia optimal, menciptakan budaya dan iklim sekolah yang kondusif dan inovatif bagi pembelajaran.

\section{KESIMPULAN}

Kepala Sekolah merupakan pimpinan tertinggi pada sebuah lembaga pendidikan. Di samping sebaai seorang pimpinan, kepala sekolah juga berperean sebagai seroang menejer yang memberikan arah serta pengatur lembaga pendidikan tersebut. sosok kepala sebagai manejer diharapkan mampu membangun dinamika pendidikan menjadi pendidikan yang bermutu. Kemampuan manajerial Kepala Sekolah harus mencakup seluruh aspek manajemen pendidikan tersebut, mulai dari pengelolaan kurikulum, peserta didik, tenaga pendidik dan kependidikan, keuangan, sarana dan prasarana, layananm khusus dan hubungan dengan masyarakat. Semua itu harus diatur sedemikian rupa agar dapat menjadikan pendidikan yang bermutu pada lembaga pendidikan.

\section{DAFTAR PUSTAKA}

Andriani, Dwi Esti. (2011). "Strategi Kepemimpinan Kepala Sekolah Dalam Upaya Mewujudkan Sekolah Efektif". Jurnal Manajemen Pendidikan No.01/Th VII/April/2011

Basri, Hasan. (2009). Filsafat Pendidikan Islam. Bandung: Pustaka Setia.

Berg, Bruce L, E book. (2001). Methods For The Social Sciences Fourth Edition

Daryanto. (2008). Administrasi Pendidikan. Jakarta: Rineka Cipta.

Heryati, Yetiti. \& Muhsin, Mumuh. (2014). Manajemen Sumber Daya Pendidikan. Bandung: Pustaka Setia.

Irianto, Agus. (2011). Pendidikan Sebagai Investasi dalam Pembangunan Suatu Bangsa. Jakarta: Kencana.

Krisna, A A, Anggi Nila, Bagian, I Wayan dan Yulianthini, Nyoman. (2015). "Pengaruh Gaya Kepemimpinan Transformasional dan Gaji Terhadap Kinerja Pegawai Pramu Bakti” Jurnal Bisma Universitas Ganesha Jurusan Manajemen Vol 3.

Mukhtar. (2015). "Strategi Kepala Sekolah Dalam Meningkatkan Kinerja Guru Pada SMP Negeri di Kecamatan Masjid Raya Kabupaten Aceh Besar" Jurnal Magister Administrasi Pendidikan Universitas Syiah Kuala Vol. 3 No. 3

Mulyasa. (2009). Menjadi Kepala Sekolah Profesional. Bandung: Rosda Karya.

Mulyasa. (2009). Standar Kompetensi dan Sertifikasi Guru. Bandung: Remaja Rosdakarya. 
Nata, Abuddin. (2005). Filsafat Pendidikan Islam. Jakarta: Gaya Media Pratama.

Prihatin, Eka. (2014). Manajemen Peserta Didik. Bandung: Alfabeta.

Qomar, Mujamil. (2010). Manajemen Pendidikan Islam. Malang: Erlangga.

Rahardja, Liana. (2010). “Analisis Peranan Manajemen Mutu Terpadu (TQM) Dalam Meningkatkan Produktivitas PT Mustika Ratu Yang Bersertifikat ISO 9002" Jurnal Ultima Accounting Vol 2. No.1.

Rohiat. (2008). Kecerdasan Emosional Kepemimpinan Kepala Sekolah. Bandung: Refika Aditama.

Rohiat. (2010). Manajemen Sekolah. Bandung: Refika Aditama.
Rosyandi, Yogi Irfan, Pardjono. (2015). "Peran Kepala Sekolah Sebagai Menejer Dalam Meningkatkan Mutu Pendidikan di SMP 1 Cilawu Garut" Jurnal Akuntabilitas Manajemen Pendidikan Vol. 3 No. 1.

Sarwono, Jonathan. (2006). Metode Penelitian Kuantitatif dan Kualitatif. Yogyakarta: Graha Ilmu.

Sa'ud, Udin Syaefudin \& Makmun, Abin Syamsuddin. (2009). Perencanaan Pendidikan Suatu Pendekatan Komprehensif. Bandung: PT Remaja Rosdakarya.

Sukmadinata, Nana Syaodih. (2010). Metode Penelitian Pendidikan, Bandung: Rosda Karya. 